\title{
Comparative description and discussion of spermiogenesis and spermatozoal ultrastructure in some species of Heptapteridae and Pseudopimelodidae (Teleostei: Siluriformes)
}

\author{
Irani Quagio-Grassiotto, Maria Angélica Spadella, \\ Márcio de Carvalho, and Claudio Oliveira
}

The data obtained in the present study on spermiogenesis and spermatozoal ultrastructure of Pseudopimelodidae and Heptapteridae show that they share some characteristics, but greatly differ from each other. The main differences are the occurrence of type I spermiogenesis in Pseudopimelodidae and type III in Heptapteridae, the presence of nuclear fossa in Pseudopimelodidae and its absence in Heptapteridae, the presence of long midpiece in Pseudopimelodidae and short midpiece in Heptapteridae, the presence of cytoplasmic canal in Pseudopimelodidae and its absence in Heptapteridae, the presence of many large vesicles in the midpiece of Pseudopimelodidae and the presence of very long vesicles placed in the peripheral distal region in Heptapteridae, and mitochondria distributed all over the midpiece in Pseudopimelodidae, and very close to the nucleus in Heptapteridae. Heptapteridae and Pimelodidae share several characteristics, such as type III spermiogenesis, a similar chromatin condensation pattern, and the absence of nuclear fossa and flagellar lateral fins. The spermatozoa of Pseudopimelodidae is more similar to those of Siluridae. However, the absence of additional data on spermiogenesis and spermatozoa in siluriforms still limits a broader discussion in the order.

Os dados obtidos no presente estudo sobre a ultraestrutura da espermiogênese e dos espermatozóides de Pseudopimelodidae e Heptapteridae mostram que eles compartilham algumas características, mas são bastante diferentes uns dos outros. As principais diferenças são a ocorrência de espermiogênese do tipo I em Pseudopimelodidae e do tipo III em Heptapteridae, a presença de fossa nuclear em Pseudopimelodidae e sua ausência em Heptapteridae, a presença de uma peça intermediária longa em Pseudopimelodidae e uma peça intermediária curta em Heptapteridae, a presença de um canal citoplasmático em Pseudopimelodidae e sua ausência em Heptapteridae, a presença de muitas vesículas grandes na peça intermediária de Pseudopimelodidae, e a presença de vesículas muito alongadas e dispostas em posição periférica distal em Heptapteridae e mitocôndrias distribuídas em toda a peça intermediária de Pseudopimelodidae e muito próximas ao núcleo em Heptapteridae. Heptapteridae e Pimelodidae compartilham várias características como a espermiogênese do tipo III, o mesmo padrão de condensação da cromatina e a ausência de fossa nuclear e projeções laterais ou fins. O espermatozóide de Pseudopimelodidae é mais similar aos dos Siluridae, porém a ausência de dados adicionais sobre a espermiogênese e o espermatozóide de outros siluriformes ainda limitam uma discussão mais ampla na ordem.

Key words: catfish, spermatid, sperm, structure, phylogeny.

\section{Introduction}

Siluriformes comprise the most diverse and widely distributed ostariophysan group and represent about $32 \%$ of all freshwater fishes (Teugels, 1996). The relationships among catfish families have long been studied, but the higher-level phylogeny of siluriforms is still controversial (Diogo, 2003). It is a general consensus that the family Diplomystidae is the sister group of all other Siluriforms. According to the phylogeny proposed by Britto (2003), the families Pimelodidae, Heptapteridae and Pseudopimelodidae belong to a monophyletic clade that includes Anchariidae, Austroglanididae, Bagridae, Claroteinae, Cranoglanididae, Doradoidei, Pangasiidae, Schilbidae, and Horabagrus. In his phylogeny,

Depto. de Morfologia, Instituto de Biociências - Botucatu, Universidade Estadual Paulista - UNESP, C.P. 510 , $18618-000$ Botucatu, SP, Brazil. e-mail: morfologia@ibb.unesp.br 
Pseudopimelodidae and Heptapteridae appear as a monophyletic group, as well as the most basal group of this clade. Pimelodidae occupy a more derived position and is the sistergroup of the clade formed by Anchariidae, Austroglanididae, Bagridae, Claroteinae, Cranoglanididae, Pangasiidae, Schilbidae and Horabagrus (Britto, 2003).

Pseudopimelodidae may be considered the least known and one of the smallest families of neotropical freshwater catfishes (Shibatta, 2003). Lundberg et al. (1991) first demonstrated the monophyly of this group and suggested the existence of a relationship between Pseudopimelodidae and the basal Heptapteridae. This hypothesis was corroborated by Britto (2003). The family Heptapteridae comprises small to medium-sized fishes and forms one of the largest group of Neotropical catfishes (Bockmann \& Guazzelli, 2003). Bockmann (1998) considered Goeldiella as the sister group of all other Heptapteridae. The remaining Heptapteridae were divided into three clades: one composed by Rhamdia quelen, another by R. laticauda and Pimelodella, and the other by the remaining species (Bockmann, 1998).

Although the current knowledge of the relationship pattern among Siluriformes has been acquired on the basis of morphological characters, other data seem to be potentially useful for the study of this group. Within this framework, spermatogenesis and spermatozoal ultrastructure have been studied in several fish groups (Jamieson, 1991; Mattei, 1970; 1991) and the usefulness of this type of data in the clarification of the relationship among some families has been fully recognized. Based on the phylogeny proposed by Britto (2003), with the exception of Sisoroidea, Amphiliidae, and Loricarioidea, detailed descriptions of spermatozoa are currently available only for some species of the following catfish families: Diplomystidae (Quagio-Grassiotto et al., 2001), Clariidae (Mansour et al., 2002), Siluridae (Emel'yanova \& Makeyeva, 1991b; Kwon et al., 1998; Lee \& Kim, 2001), Ictaluridae (Jaspers et al., 1976; Poirier \& Nicholson, 1982; Emel'yanova \& Makeyeva, 1991a,b), Auchenipteridae (Burns et al., 2002), Pimelodidae (Quagio-Grassiotto \& Carvalho, 2000; Quagio-Grassiotto \& Oliveira, in press) and Bagridae (Emel'yanova \& Makeyeva, 1991b; Lee, 1998; Kim \& Lee, 2000). General information is found about the spermatozoa of Heteropneustidae (Nath \& Chand, 1998), Malapteruridae, Mochokidae, Schilbidae, and Ariidae (Mattei, 1991-schematic drawings), and Conorhynchus conirostris (Lopes et al., 2004). There is no information about the sperm cell of the Anchariidae, Auchenoglanidinae, Austroglanididae, Chacidae, Claroteinae, Cranoglanididae, Doradidae, Heptapteridae, Horabagrus, Pangasiidae, Plotosidae, or Pseudopimelodidae.

Considering their informative phylogenetic potential, the ultrastructural characters of both spermiogenesis and spermatozoa in one genus of Pseudopimelodidae (Microglanis) and two species of two genera of Heptapteridae (Rhamdia and Pimelodella) are herein described for the first time and data are compared and discussed.

\section{Materials and Methods}

The present study was conducted with five to ten adult males of Rhamdia quelen (Heptapteridae) (catalog number: LBP 1345) and Microglanis aff. parahybae (Pseudopimelodidae) (catalog numbers: LBP 1193, LBP 1308 and LBP 1315) collected from the rio Araquá, Botucatu, São Paulo, Brazil (22 $47.135^{\prime}$ 'S, 48 $\left.28.892^{\prime} \mathrm{W}\right)$ and Pimelodella gracilis (Heptapteridae) (catalog number: LBP 1741) collected from the rio Alambari, Botucatu, São Paulo, Brazil (22 $56^{\prime} 08^{\prime \prime}$ S, $\left.48^{\circ} 19^{\prime} 15^{\prime \prime} \mathrm{W}\right)$. The fishes were identified and kept in the fish collection of Laboratório de Biologia e Genética de Peixes (LBP), Departamento de Morfologia, Instituto de Biociências, UNESP, Botucatu, São Paulo, Brazil.

Gonad fragments from newly sacrificed fish were fixed overnight in $2 \%$ glutaraldehyde and $4 \%$ paraformaldehyde in $0.1 \mathrm{M}$ Sorensen phosphate buffer, $\mathrm{pH}$ 7.4. The material was post-fixed in the dark for 2 hours in $1 \%$ osmium tetroxide in the same buffer, stained in block with an aqueous solution of $5 \%$ uranyl acetate for two hours, dehydrated in acetone, embedded in araldite, and sectioned and stained with a saturated solution of uranyl acetate in $50 \%$ alcohol and lead citrate. Electron micrographs were obtained using a Phillips CM 100 transmission electron microscope.

\section{Results}

General observations. In the species analyzed, spermiogenesis occurs in cysts in the germinative epithelium. These cysts consist of a group of germ cells at the same developmental stage, which are surrounded by cytoplasmic processes of Sertoli cells. In the cysts, the early spermatids are interconnected by cytoplasmic bridges resultant from incomplete cytokinesis of both the anterior mitotic and the meiotic divisions. In all the species, spermatozoa exhibit a head, a midpiece, and one tail or flagellum. The head does not have an acrosomal vesicle.

Pseudopimelodidae spermiogenesis. In M. aff. parahybae early spermatids, the cytoplasm symmetrically encircles the nucleus, which shows diffuse homogenous chromatin, and has a circular outline. The centriolar complex lies laterally to the nucleus and anchors to the plasma membrane. The proximal centriole is anterior, oriented end-by-end and slightly oblique in relation to the distal centriole. The distal centriole differentiates into the basal body and forms the flagellum. The centriolar complex moves toward the nucleus, carrying along the plasma membrane and the initial segment of the flagellum, which invaginates. The cytoplasmic channel, a space between the flagellum and the plasma membrane, is then formed (Figs. 1A-H). A depression is formed in the nuclear outline at the level of the centriolar complex. The nucleus starts to rotate, making the centriolar complex penetrate the newly formed depression. Most of the cytoplasm moves towards the region surrounding the cytoplasmic channel where a few mitochondria are located, and gives rise to the midpiece (Figs. 1E-G, 1J). Many vesicles 
appear at the midpiece. These vesicles elongate and fuse to each other and to the plasma membrane (Figs. 1L-O). In the final spermatids, the nucleus contains highly condensed homogeneous chromatin (Fig. 1G). The flagellum exhibits the classical $(9+2)$ axoneme, surrounded by the flagellar membrane, and does not form lateral fins (Figs. 1I-K).

Heptapteridae spermiogenesis. In Heptapteridae early sper- matids, the cytoplasm symmetrically encircles the nucleus, which shows diffuse homogenous chromatin, and has a circular outline. The centriolar complex lies medially and close to the nucleus (Figs. 2B-C, 3A-B). In R. quelen, the proximal centriole is anterior, lateral and perpendicular to the distal centriole (Figs. 2B, 2D, 2G), while in $P$. gracilis it is parallel to the distal centriole (Figs. 3A-C). The distal centriole differentiates into the basal body. It remains associated with the

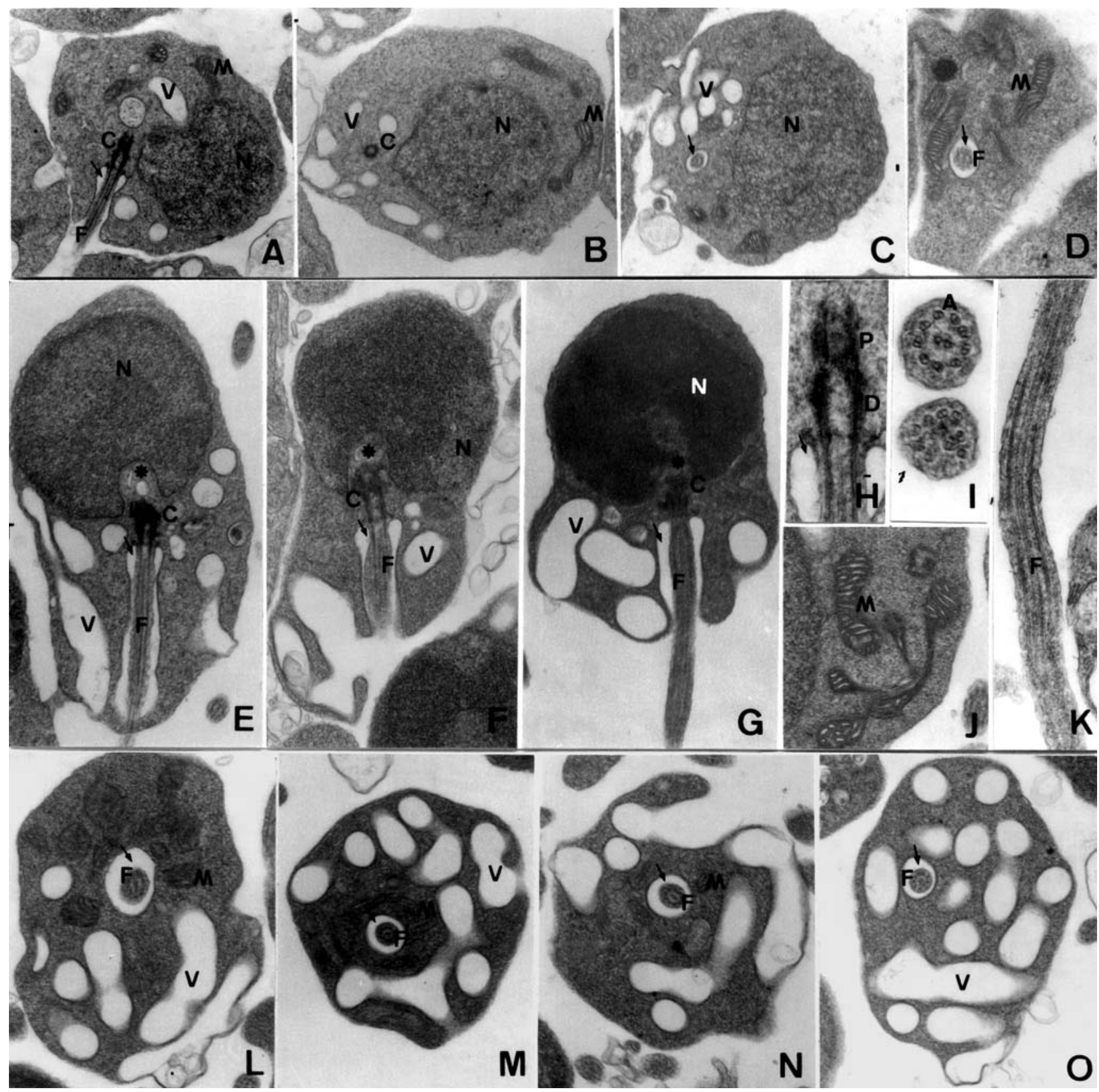

Fig. 1. Microglanis aff. parahybae spermatids. A-D: early spermatids in longitudinal (A) and cross sections (B-D). A: X 10200; B: X 9750; C: 9750; D: X 13600. E-G: spermatids in longitudinal sections. E: X 13600; F: X 18400; G: X 13600. H: centriolar complex. H: X 34000. I: flagellum in cross section. I: X 59000. J: mitochondria. J: X 17200. K: flagellum in longitudinal section. K: X 23800. L-O: midpieces in longitudinal sections. L: X 18400; M: X 16100; N: X 17000; O: X 17000. A: axonema; C: centriolar complex; D: distal centriole; F: flagellum; M: mitochondria; N: nucleus; P: proximal centriole; V: vesicle; arrow: cytoplasmic channel; asterisks: nuclear fossa. 


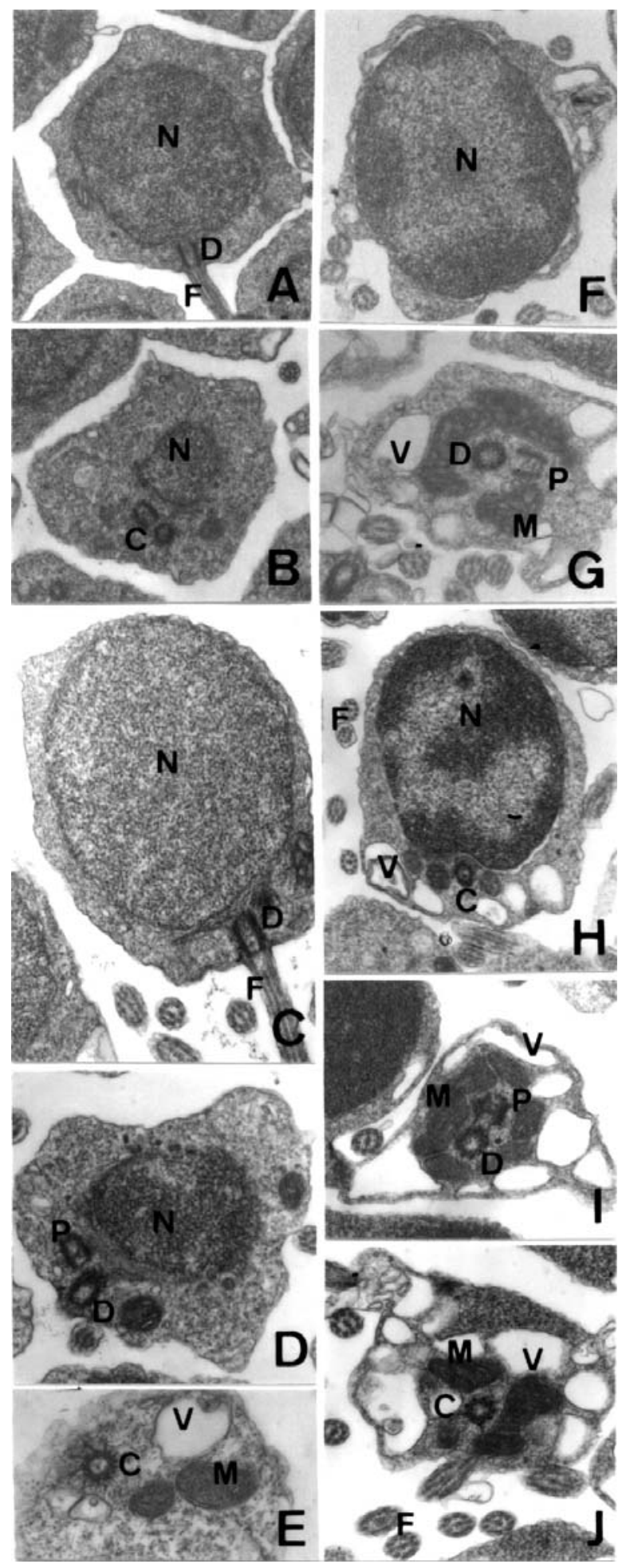

Fig. 2. Rhamdia quelen spermatids. A, C: early spermatids in longitudinal sections. A: X 9300; C: X 15800. B, D: early spermatids oblique sections at the nuclear basal region. B: X 10600; D: X 15800. F, H: nucleus in longitudinal sections. F: X 16500; H: X 11900. E, G, I, J: midpieces in longitudinal sections. E: X 11500; G: X 14500; I: X 17000; J: X 15800. C: centriolar complex; D: distal centriole; F: flagellum; M: mitochondria; N: nucleus; P: proximal centriole; V: vesicle. plasma membrane and forms the flagellum (Figs. 2A, 2C, 2E, 3B-3D). In the nucleus, during spermatid differentiation, areas of progressive and homogeneous condensed chromatin are seen among other more diffuse areas. The nucleus does not rotate and the nuclear fossa is not formed (Figs. 2F-H, 3B3D). In R. quelen, the nucleus becomes slightly elongate (Figs. $2 \mathrm{C}, 2 \mathrm{~F}, 2 \mathrm{H})$. The cytoplasmic mass moves to the initial segment of the flagellum and gives rise to the midpiece with a pseudo-cytoplasmatic channel of the future spermatozoon (Figs. 2H, 3D). The few mitochondria initially found around the nucleus are now located around the centriolar complex, near the nucleus, in the midpiece anterior region. They are long, have many cristae and an electron-dense matrix (Figs. 2E, 2G, 2I-J, 3C, 3E, 3F). Many vesicles appear at the midpiece peripheral and distal end-regions. These vesicles elongate, fuse to each other and become very long and interspersed with a narrow strip of cytoplasm (Figs. 2E, 2G-J, 3D-F). In $P$. gracilis, the displacement of these vesicles to the initial region of the tail may form a short pseudo-cytoplasmic channel, which does not remain in the spermatozoa (Figs. 3D, 3F). The flagellum exhibits the classical $9+2$ axoneme, surrounded by the flagellar membrane that does not form lateral fins (Figs. $2 \mathrm{C}, 2 \mathrm{H}, 3 \mathrm{~F})$.

Pseudopimelodidae spermatozoa. In the Pseudopimelodidae spermatozoa, the head is formed by the nucleus that has a circular outline, is occupied by highly condensed homogeneous chromatin, and surrounded by a narrow strip of cytoplasm with no organelles (Figs. 4A-B). In the nuclear outline, there is a nuclear fossa of the moderate type containing only the proximal centriole (Fig. 4D-Inset) and part of the distal centriole. The proximal centriole is anterior, oriented end-byend and slightly oblique to the basal body. The flagellum is medial and perpendicular to the nucleus (Fig. 4C). An electron-dense material are found surrounding the centriolar complex (Fig. 4C). The midpiece is long, wide, and slightly asymmetric, with a long cytoplasmic channel. Few elongate mitochondria and many vesicles that are connected to each other and also to the plasma membrane are scattered all over the midpiece (Figs. 4D-F). The single tail or flagellum contains the classical axoneme $(9+2)$, and the flagellar membrane does not have lateral fins (Figs. 4A, 4C, 4E).

Heptapteridae spermatozoa. In the Heptapteridae spermatozoa, the head is formed by the nucleus that does not shows a nuclear fossa. The nucleus is surrounded by a narrow strip of cytoplasm with no organelles. The nucleus is occupied by highly condensed homogeneous chromatin and displays some electron-lucent areas (Figs. 5A-B, 6A-B). R. quelen spermatozoa have an ovoid head with an ovoid nucleus (Fig. 5A), while in $P$. gracilis, the head and the nucleus are round (Fig. 6A). The centriolar complex remains close to the nucleus and is surrounded by a thin layer of electron-dense material (Figs. $5 \mathrm{~A}, 5 \mathrm{E}, 5 \mathrm{~F}, 6 \mathrm{~A}, 6 \mathrm{E})$. In $R$. quelen, the proximal centriole is anterior, lateral and perpendicular to the flagellum basal body - the differentiated distal centriole (Figs. 5E-F), while in $P$. 


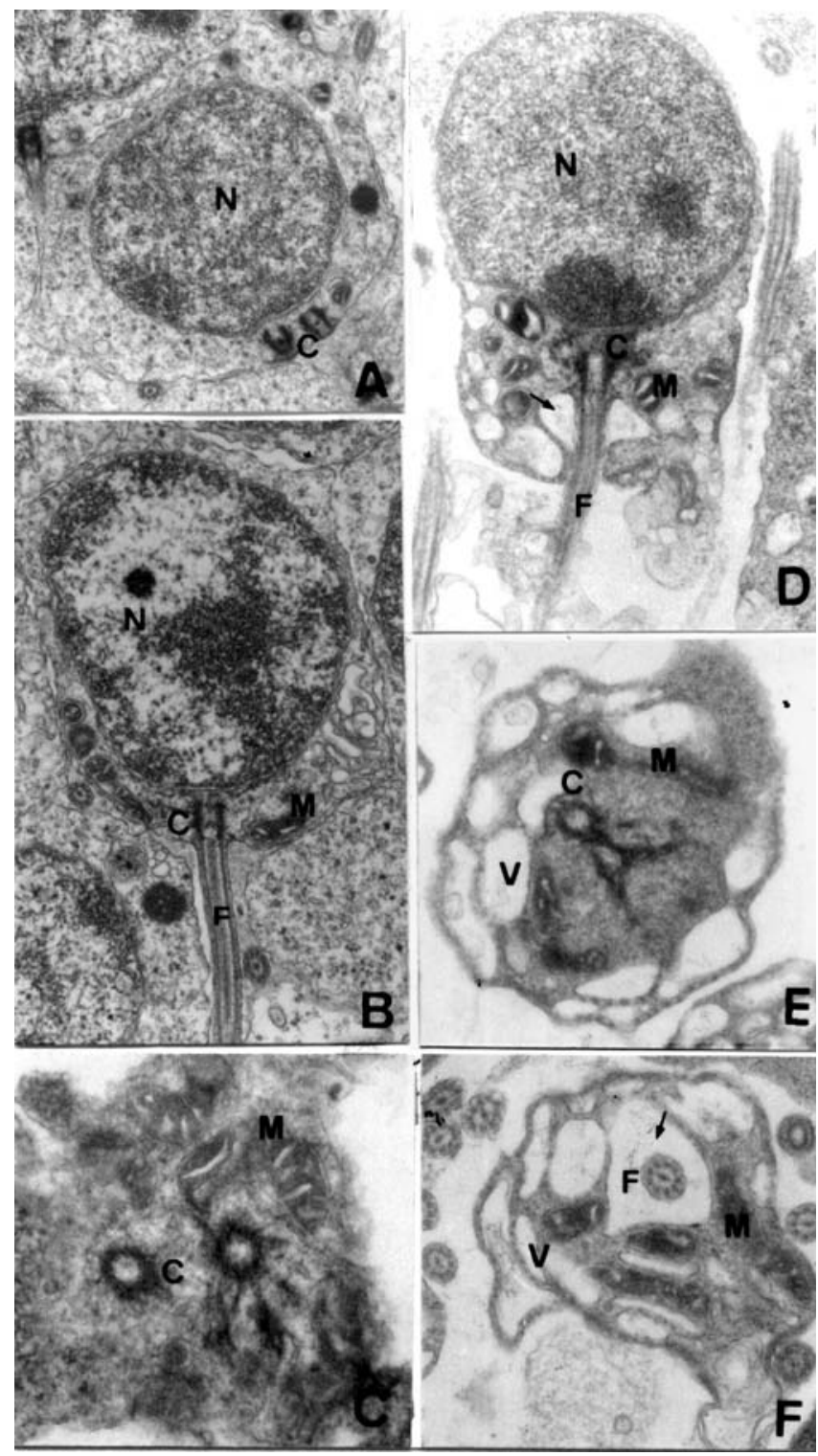

Fig. 3. Pimelodella gracilis spermatids. A: early spermatids in longitudinal section. A: X 12000. B, D: longitudinal sections. B: X 13000; D: X 14500. C, E, F: midpieces in cross sections. C: X 23200; E: X 21000; F: 18900. C: centriolar complex; F: flagellum; M: mitochondria; N: nucleus; V: vesicle; arrow: pseudo-cytoplasmic channel.

gracilis, the proximal centriole is anterior, lateral and coaxial to the basal body (Fig. 6D-F). In the midpiece, the few mitochondria are elongate, fused to each other, and located near the nucleus around the centriolar complex. The mitochondria are very close to the nucleus, forming a sleeve around the initial segment of the axoneme (Figs. 5F-I, 6C, 6F-G). In $R$. quelen, these organelles are separated from the axoneme by an internal long and narrow cistern (Figs. 5E, 5G-H). In $P$. gracilis, the internal cistern is not present. The midpiece cytoplasmic mass is reduced. The vesicles located in the peripheral and distal regions of the midpiece are very long and interspersed with a narrow strip of cytoplasm. They form true membranous loops at the midpiece end (Figs. 5E, 6E). The single tail or flagellum contains the classical axoneme $(9+2)$, and the flagellar membrane does not form lateral fins (Figs. 5C-D, 6H).

\section{Discussion}

Spermiogenesis. Teleostei with external fertilization showed that the flagellum generally develops lateral to the nucleus in the early spermatids. In spermatozoa, the flagellar axis may be either perpendicular or parallel to the nucleus, depending on whether nuclear rotation occurs (type I spermiogenesis) or not (type II spermiogenesis) during spermiogenesis (Mattei, 1970). In the pimelodid (Quagio-Grassiotto and Oliveira, in press) the flagellum development is medial, the nucleus does not rotate, and both the nuclear fossa and the cytoplasmic channel are absent during spermiogenesis. These characteristics have not been found in any other fish species and represents a new type of spermiogenesis named type III. In Pseudopimelodidae, spermiogenesis is of type I. In Diplomystidae, the most basal family of Siluriformes, spermiogenesis is also of type I, though in this family the cytoplasmic channel does not remain in the spermatozoon (QuagioGrassiotto et al., 2001). On the other hand, in Heptapteridae, spermiogenesis is of type III, as observed in Pimelodidae (Quagio-Grassiotto \& Oliveira, in press). In Heptapteridae and Pimelodidae, a short pseudo-cytoplasmic channel may appear as the cytoplasmic mass moves toward the flagellum, and the midpiece vesicles fuse to each other and to the plasma membrane. No information about spermiogenesis in other Siluriform families with external fertilization is available.

Spermatozoa nuclear characteristics. Homogeneous and highly condensed chromatin with some small, round, scattered electron-lucent areas is found in spermatozoa of Pseudopimelodidae, Heptapteridae and Pimelodidae (QuagioGrassiotto \& Carvalho, 2000; Santos et al., 2001; QuagioGrassiotto \& Oliveira, in press). This type of chromatin condensation is very frequent among the siluriform spermatozoa and is found in Siluridae (Emel'yanova \& Makeyeva, 1991b; Kwon et al., 1998; Lee \& Kim, 2001), Ictaluridae (Poirier \& Nicholson, 1982; Emel'yanova \& Makeyeva, 1991a,b), Auchenipteridae (Burns et al., 2002), and Bagridae (Emel'yanova \& Makeyeva, 1991b; Lee, 1998; Kim \& Lee, 2000). In Conorhynchus conirostris (Lopes et al., 2004), now Incertae Sedis in Siluriformes (Ferraris, 2003), the chromatin apparently forms highly condensed clusters, as observed in Diplomystidae (Quagio-Grassiotto et al., 2001), Clariidae (Mansour et al., 2002), and Heteropneustidae (Nath \& Chand, 1998). No information on chromatin condensation is available for members of the other Siluriform families documented by Mattei (1991-schematic drawings).

The round nucleus observed in the spermatozoa of Pseudopimelodidae (present paper), the Heptapteridae species P. gracilis (present paper), and Pimelodidae (QuagioGrassiotto \& Carvalho, 2000; Santos et al., 2001; Quagio- 


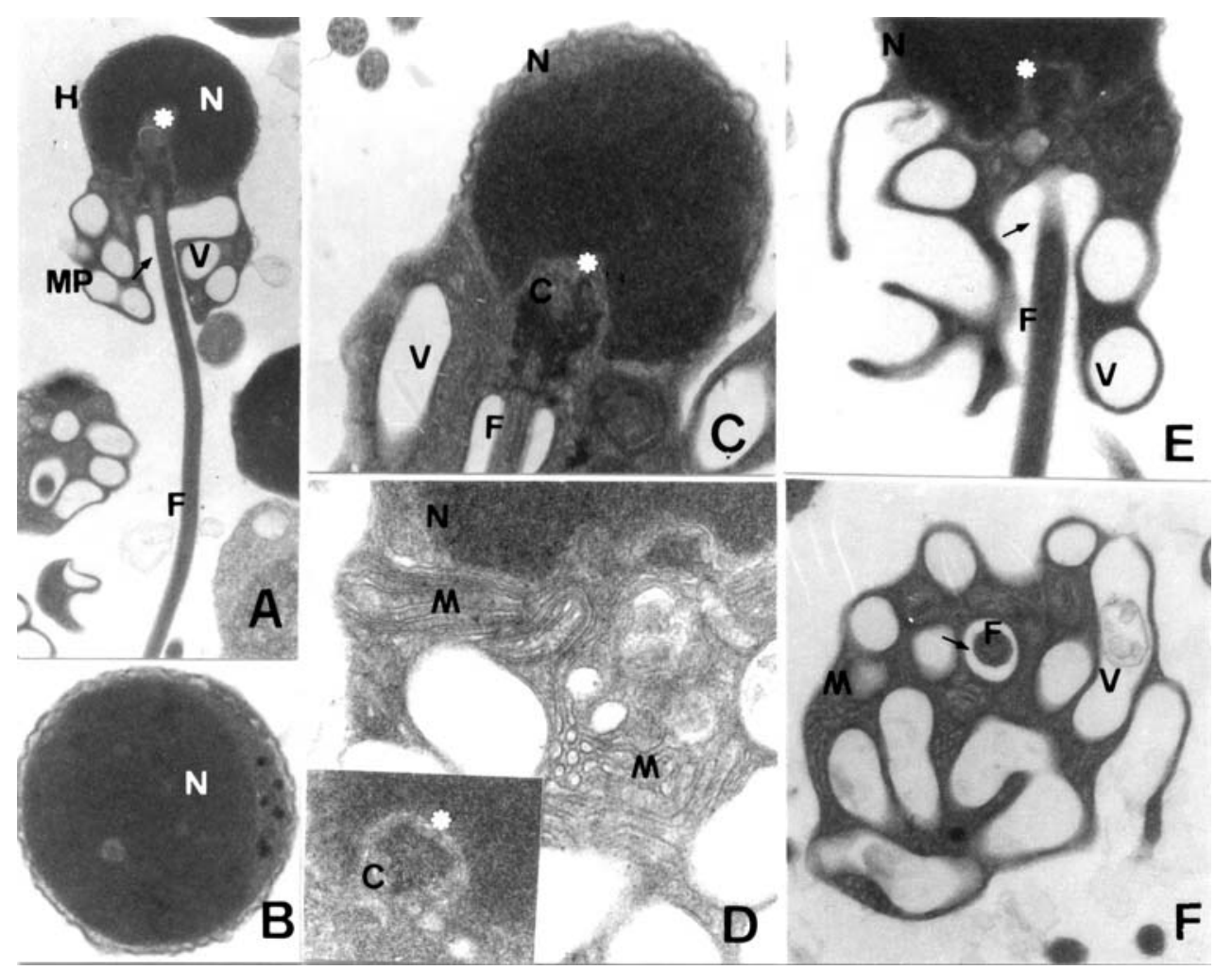

Fig. 4. Microglanis aff. parahybae spermatozoa. A: longitudinal section. A: X 9800. B: nucleus in cross section. B: X 17000. C: longitudinal sectional of the head and initial midpiece region. C: X 23000. D-E: midpieces in longitudinal sections. D: X 31500; E: X 21500. Insert: proximal centriole. X 59000. F: midpiece in cross sections. F: X 17000. C: centriolar complex; F: flagellum; H: head; M: mitochondria; MP: midpiece; N: nucleus; V: vesicle; arrow: cytoplasmic channel; asterisks: nuclear fossa.

Grassiotto \& Oliveira, in press), is a common characteristic among Siluriformes. This type of nuclear outline occurs in Diplomystidae (Quagio-Grassiotto et al., 2001), Clariidae (Mattei, 1991; Mansour et al., 2002), Heteropneustidae (Nath \& Chand, 1998), Siluridae (Emel'yanova \& Makeyeva, 1991b; Kwon et al., 1998; Lee \& Kim, 2001), Mochokidae (schematic drawings-Mattei, 1991), Bagridae (Emel'yanova \& Makeyeva, 1991b; Lee, 1998; Kim \& Lee, 2000). The ovoid nucleus seen in the Heptapteridae, R. quelen (present paper), is also observed in Conorhynchus conirostris (Lopes et al., 2004). However, the nucleus is longer in the latter than in the former. In Ictaluridae (Poirier \& Nicholson, 1982; Emel'yanova \& Makeyeva, 1991; 1992), Malapteruridae and Ariidae (schematic drawings-Mattei, 1991), the nuclear shape may be considered semi-spherical or semi-ovoid. As expected, the inseminating Auchenipteridae, Trachelyopterus lucenai has a conical and very long nucleus (Burns et al., 2002).

In the nuclear outline, a nuclear fossa of the moderate type containing only the proximal centriole and part of the distal centriole is found in Pseudopimelodidae. A similar nuclear fossa and centriolar positioning are observed in Clariidae (Mansour et al., 2002), Siluridae (Kwon et al., 1998; Lee \& Kim, 2001), and probably in Mochokidae and Schilbidae (schematic drawings-Mattei, 1991). A medial nuclear fossa of the moderate type is also exhibited by Diplomystidae (QuagioGrassiotto et al., 2001), Heteropneustidae (Nath \& Chand,
1998), and Bagridae (Lee, 1998; Kim \& Lee 2000). However, in these latter families, the centriolar complex lies completely inside the nuclear fossa. In the Heptapteridae species, the nuclear fossa is absent and the centriolar complex lies close to the nucleus, at a medial position, as observed in pimelodid (Quagio-Grassiotto \& Carvalho, 2000; Quagio-Grassiotto \& Oliveira, in press). In Iheringichthys labrosus (Santos et al., 2001), also a Pimelodidae, the medial nuclear fossa is shallow, and the centriolar complex remains in the same position as in other Pimelodidae. In Conorhynchus conirostris (Lopes et al., 2004), the medial nuclear fossa is deep and penetrates almost to the tip of the nucleus, while the centriolar complex is completely inside of it. When the nucleus is longitudinally bisected, this kind of nuclear fossa gives rise to a horseshoeshaped image. The centriolar complex in Ictaluridae (Emel'yanova \& Makeyeva, 1991a, b; Poirier \& Nicholson, 1982; Mattei, 1991), Malapteruridae and Ariidae (schematic drawings-Mattei, 1991) lies outside the nuclear fossa that forms a shallow double arc at a medial position. In the inseminating Auchenipteridae (Burns et al., 2002), the nuclear fossa can be considered as of the moderate type. It lies laterally to the nuclear outline and contains only the proximal centriole and part of the distal centriole.

Position of the centrioles in relation to each other. In Pseudopimelodidae, the proximal centriole is anterior and 


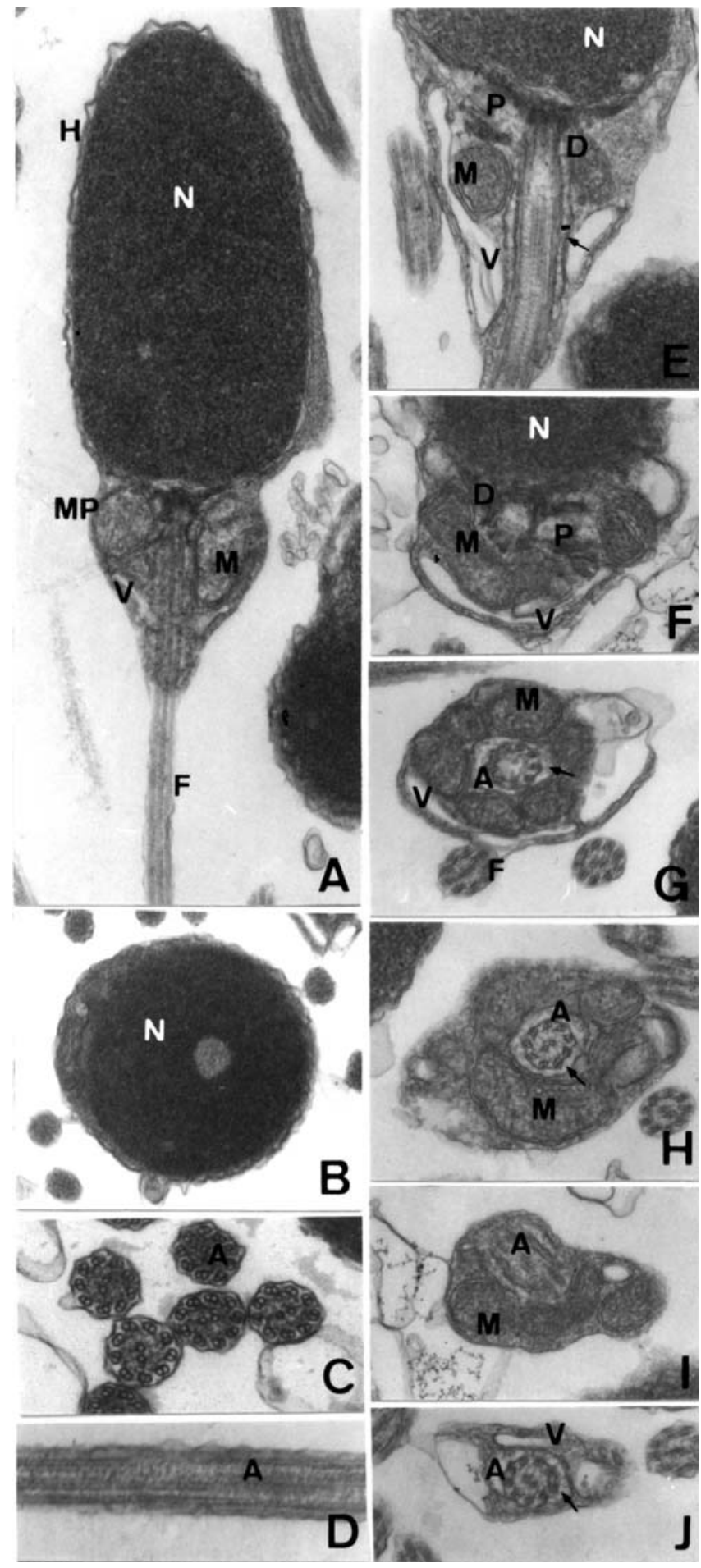

Fig. 5. Rhamdia quelen spermatozoa. A: longitudinal section. A: X 21000. B: nucleus in cross section. B: X 18000. E: midpiece in longitudinal section. E: X 27500. C, D: flagella in cross (C) and longitudinal (D) sections. C-D: X 41000. F - J: midpieces in cross sections. F-J: X 27500. A: axonema; D: distal centriole; F: flagellum; H: head; M: mitochondria; MP: midpiece; N: nucleus; P: proximal centriole; V: vesicle; arrow: cistern. slightly oblique to the distal centriole in an obtuse angle. A similar arrangement is observed in different Siluridae species, whose proximal centriole is anterior and varies from perpendicular to oblique in different obtuse angles, or even coaxial to the distal centriole (Emel'yanova \& Makeyeva; 1991b, Kwon et al., 1998; Lee \& Kim, 2001). In contrast, in the Heptapteridae species, $R$. quelen, the proximal centriole is antero-lateral, and perpendicular to the distal centriole, while in P. gracilis the proximal centriole is antero-lateral, and parallel to the distal centriole. On the other hand, in Pimelodidae (Quagio-Grassiotto \& Carvalho, 2000; Santos et al., 2001; Quagio-Grassiotto \& Oliveira, in press), the proximal centriole is anterior, and perpendicular to the distal centriole. This same arrangement is observed in Diplomystidae (QuagioGrassiotto et al., 2001) and also occurs in the inseminating Auchenipteridae (Burns et al., 2002), Mochokidae and Schilbidae Mattei (1991- schematic drawings). Clariidae (Mansour et al., 2002) and Bagridae (Emel'yanova \& Makeyeva, 1992; Lee, 1998; Kim and Lee 2000) exhibit other types of centriolar arrangements, while in the biflagellate sperm of Ictaluridae (Emel'yanova \& Makeyeva, 1991a, b; Poirier \& Nicholson, 1982; Mattei, 1991), Ariidae and Malapteruridae (Mattei, 1991- schematic drawings), the centrioles are differentiated into two basal bodies, which are lateral and parallel to each other. The illustrations of Conorhynchus conirostris (Lopes et al., 2004) and Heteropneustes fossilis (Nath \& Chand, 1998) do not provide information about the centriolar complex arrangement in these species.

Spermatozoal midpiece characteristics. Pseudopimelodidae have a long, wide, and slightly asymmetric midpiece, with a long cytoplasmic channel. Long and large midpieces are also found in the biflagellate sperm of the Ictaluridae (Poirier \& Nicholson, 1982; Emel'yanova \& Makeyeva, 1991a, b), Malapteruridae and Ariidae (Mattei 1991- schematic drawings). However, in these families the midpiece contains two cytoplasmic channels, one for each flagellum. In Heptapteridae, as in Pimelodidae (Quagio-Grassiotto \& Carvalho, 2000; Santos et al., 2001; Quagio-Grassiotto \& Oliveira, in press), the midpiece is short and devoid of a cytoplasmic channel. A short midpiece without cytoplasmic channel is also observed both in Diplomystidae (Quagio-Grassiotto et al., 2001) and in Clariidae (Mansour et al., 2002). The short midpiece observed in Bagridae (Emel'yanova \& Makeyeva, 1991b; Lee, 1998; Kim \& Lee, 2000) and Siluridae (Mattei, 1991; Emel'yanova \& Makeyeva, 1991b; Kwon et al., 1998; Lee \& Kim, 2001) has a short cytoplasmic channel. The same occurs in the Mochokidae and Schilbidae (Mattei, 1991 - schematic drawings). In contrast, in the inseminating Auchenipteridae, the midpiece is long and strongly asymmetric, and has a lateral cytoplasmic channel (Burns et al., 2002). The illustrations of Conorhynchus conirostris (Lopes et al., 2004) and Heteropneustes fossilis (Nath \& Chand, 1998) do not provide clear information about the cytoplasmic channel in these species.

Many large vesicles, or cisternae, interconnected to each 


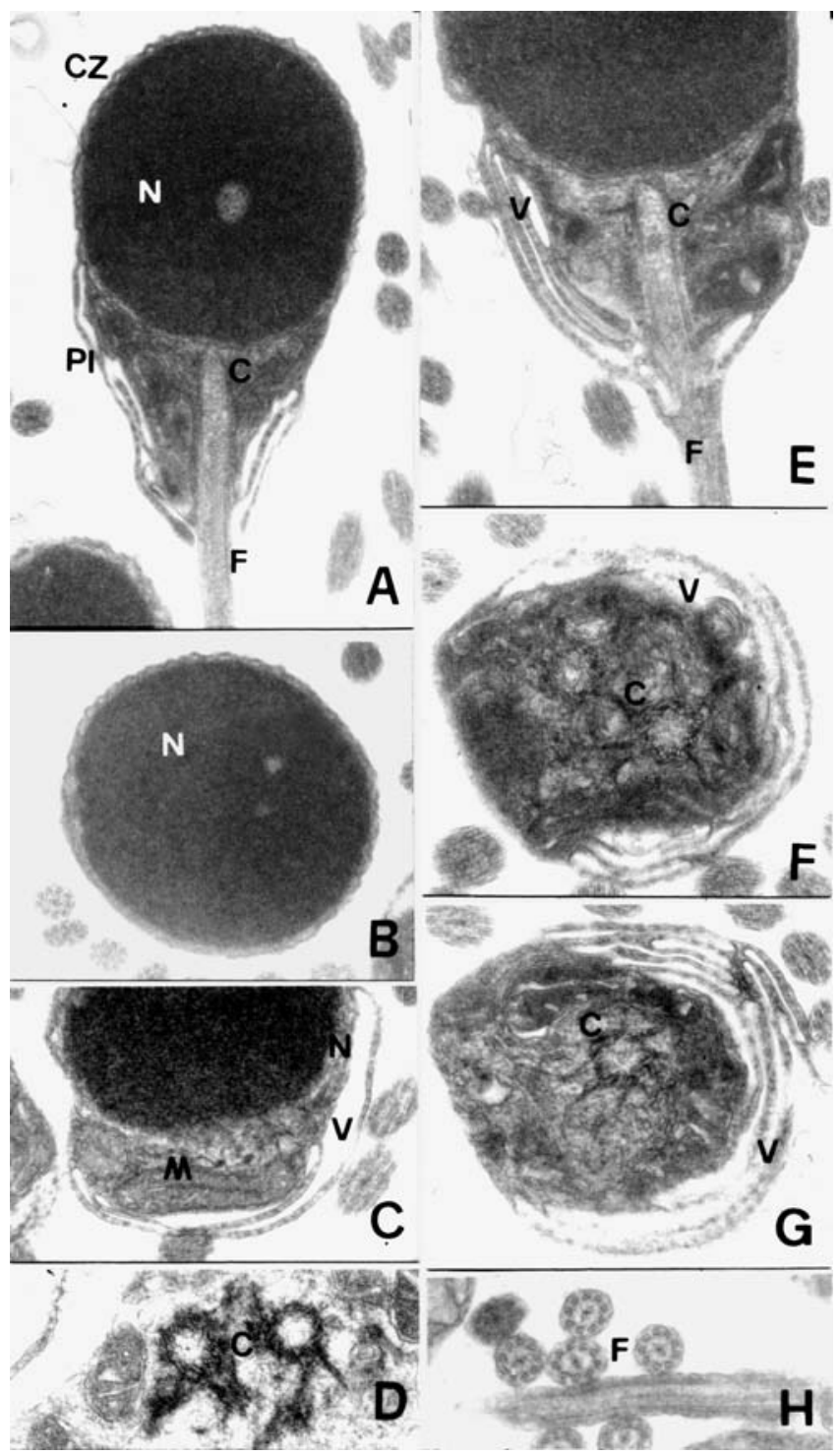

Fig. 6. Pimelodella gracilis spermatozoa. A: longitudinal section. A: X 21000. B: nucleus in cross section. B: X 21000. C, E: midpiece in longitudinal sections. C: X 20300; E: X 25200. D, F, G: midpieces in cross sections. D: X 29700; F: X 29400; G: X 29000. H: flagella in cross and longitudinal sections. $\mathbf{H}: \mathbf{X}$ 25200. C: centriolar complex; F: flagellum; H: head; M: mitochondria; MP: midpiece; N: nucleus; V: vesicle.

other and to the plasma membrane are observed in the midpiece of Pseudopimelodidae. The same type of vesicles is found in Pimelodidae (Quagio-Grassiotto \& Carvalho, 2000; Santos et al., 2001; Quagio-Grassiotto \& Oliveira, in press) and in Ictaluridae (Poirier \& Nicholson, 1982; Emel'yanova \& Makeyeva, 1991a, b). In the midpiece of Heptapteridae, the vesicles are very long, interspersed with a narrow strip of cytoplasm placed in the peripheral distal region and projected to the flagellum initial segment. Other types of well-developed and organized vesicle systems occur in Clariidae (Mansour et al., 2002) and Siluridae (Emel'yanova \& Makeyeva, 1991b; Kwon et al., 1998; Lee \& Kim, 2001). The vesicles may also be absents, as in the midpiece of Diplomystidae (Quagio-Grassiotto, et al., 2001), Auchenipteridae (Burns et al., 2002), and Bagridae (Emel'yanova \& Makeyeva, 1991b; Lee, 1998; Kim \& Lee 2000). No information about midpiece vesicles is provided in Mattei's (1991) schematic drawings of Malapteruridae, Mochokidae, Schilbidae or Ariidae.

In Pseudopimelodidae, the few elongate mitochondria are distributed all over the midpiece, near the nucleus, directly around the basal body, and are separated from the axoneme by the cytoplasmic channel. The same occurs in Siluridae (Mattei, 1991; Emel'yanova \& Makeyeva, 1991b; Kwon et al., 1998; Lee \& Kim, 2001). In Heptapteridae, mitochondria are also few and elongate. They are very close to the nucleus, may be fused and form a sleeve around the axoneme initial segment. In Pimelodidae, mitochondria are oblong or elongate and located near the nucleus. They form a ring around the centriolar complex (Quagio-Grassiotto \& Carvalho, 2000; Quagio-Grassiotto, in press), and, as in Clariidae (Mansour et al., 2002) and are apparently fused. In the other Siluriform families, mitochondria vary from a single unit, as in Diplomystidae (Quagio-Grassiotto, et al., 2001), to multiple units, as in Auchenipteridae (Burns et al., 2002). Several mitochondria are found in other groups such as Clariidae (Mansour et al., 2002), Bagridae (Emel'yanova \& Makeyeva, 1991b; Lee, 1998; Kim \& Lee, 2000), Ictaluridae (Poirier \& Nicholson, 1982; Emel'yanova \& Makeyeva, 1991a, b), Malapteruridae, Mochokidae, Schilbidae and Ariidae and Malapteruridae (Mattei, 1991-schematic drawings). In these families, mitochondria have different forms and distribution patterns within the midpiece.

Spermatozoa flagellar characteristics. Spermatozoa with a single and medial flagellum are the most frequent sperm form seen in Siluriforms. This was also found in the Pseudopimelodidae and Heptapteridae analyzed herein. This is the sperm form of Diplomystidae (Quagio-Grassiotto et al., 2001), Clariidae (schematic drawings-Mattei, 1991; Mansour et al., 2002), Siluridae (Emel'yanova \& Makeyeva, 1991b; Kwon et al., 1998; Lee \& Kim, 2001), Mochokidae (schematic drawings-Mattei, 1991), Bagridae (Emel'yanova \& Makeyeva, 1991b; Lee, 1998; Kim \& Lee, 2000), Schilbidae (schematic drawings-Mattei, 1991), Conorhynchus conirostris (Lopes et al., 2004) and Heteropneustes fossilis (Nath \& Chand, 1998). However, Maggese et al. (1984), who analyzed the spermatozoa of the Heptapteridae Rhamdia sapo (a junior synonymous with $R$. quelen) under scanning electron microscopy, suggested that those fishes had two flagella. The biflagellate sperm is found in Ictaluridae (Emel'yanova \& Makeyeva, 1991a, b; Poirier \& Nicholson, 1982; Mattei, 1991), Malapteruridae (schematic drawings-Mattei, 1991) and Ariidae (schematic drawings-Mattei, 1991). In the inseminating Auchenipteridae (Burns et al., 2002), the flagellum is single and lateral.

The flagellum of the Pseudopimelodidae and Heptapteridae herein analyzed, as well as in Pimelodidae (Quagio- 
Grassiotto \& Carvalho, 2000; Santos et al., 2001; QuagioGrassiotto \& Oliveira, in press) spermatozoa do not have lateral fins. This characteristic is shared by the majority of the other families of Siluriformes whose spermatozoa are known, except for Diplomystidae (Quagio-Grassiotto et al., 2001) and Bagridae (Emel'yanova \& Makeyeva, 1991b; Lee, 1998; Kim \& Lee 2000). In these families, the flagellar membrane shows two lateral fins.

Conclusions. The general characteristics observed in the spermatozoa of two species of Heptapteridae were very similar, which reinforces the early hypothesis developed by Baccetti et al. (1984), who suggested that species from a same family exhibit the same patterns of spermatozoon organelle distribution and agrees with the hypothesis of the monophyly of Heptapteridae (Bockmann, 1998).

Britto (2003), in a phylogenetic study of morphological characters, suggested that Pseudopimelodidae and Heptapteridae were sister groups. The present data show that Pseudopimelodidae and Heptapteridae share some characteristics, but greatly differ from each other. The main differences are the occurrence of type I spermiogenesis in Pseudopimelodidae and type III in Heptapteridae, the presence of a nuclear fossa in Pseudopimelodidae and its absence in Heptapteridae, the presence of a long midpiece in Pseudopimelodidae and short midpiece in Heptapteridae, the presence of a cytoplasmic canal in Pseudopimelodidae and its absence in Heptapteridae, many large vesicles in the midpiece of Pseudopimelodidae and vesicles very long and placed in the peripheral distal region in Heptapteridae, and mitochondria distributed all over the midpiece in Pseudopimelodidae and very close to the nucleus in Heptapteridae.

On the other hand, Heptapteridae and Pimelodidae (Quagio-Grassiotto \& Carvalho, 2000; Santos et al., 2001, Quagio-Grassiotto \& Oliveira, in press) share several characteristics, such as the same type of spermiogenesis (Type III with the formation of a medial flagellum and no nuclear rotation), the same chromatin condensation pattern, and no nuclear fossa or flagellar lateral fins.

Although the absence of additional spermiogenesis and spermatozoa data limited a broad discussion, the information currently available points to an interesting similarity between the spermatozoa of Pseudopimelodidae and Siluridae. The spermatozoa of these two families share a nuclear fossa of the moderate type, containing only the proximal centriole and part of the distal centriole, the proximal centriole anterior and slightly oblique, in an obtuse angle in relation to the distal centriole, and few elongate mitochondria distributed all over the midpiece, near the nucleus, directly around the basal body and separated from the axoneme by the cytoplasmic channel.

In addition, the ultrastructural differences observed between the spermatozoa of Conorhynchus conirostris and those of Pseudopimelodidae, Heptapteridae and Pimelodidae (previously considered to belong to the large family of Pimelodidae) support the proposal by Ferraris (2003), accord- ing to whom Conorhynchus conirostris does not appear to belong to any of those three families. A detailed analysis of C. conirostris spermatozoa does not permit a safe conclusion about the relationship of this species with other families, whose spermatozoa were previously described. On the other hand, some of the characteristics found in the spermatozoa of C. conirostris are similar to those observed in a species of Doradidae of the genus Anadoras (I. Quagio-Grassiotto, unpublished data).

\section{Acknowledgments}

We would like to thank E.M. Laboratory/IBB-UNESP for allowing us to use their facilities and to O. A. Shibatta for the taxonomic identification of Microglanis aff. parahybae. This research was supported by the Brazilian Agencies CAUNESP (Centro de Aqüicultura da Universidade Estadual Paulista), FAPESP (Fundação de Apoio à Pesquisa do Estado de São Paulo), and CNPQ (Conselho Nacional de Desenvolvimento Científico e Tecnológico).

\section{Literature Cited}

Baccetti, B., A. G. Burrini, G. Callaini, G. Gilbertini, M. Mazzini \& S. Zerunian. 1984. Fish germinal cells. I. Comparative spermatology of seven cyprinid species. Gamete Research, 10:373-396.

Bockmann, F. A. 1998. Análise filogenética da família Heptapteridae (Teleostei, Ostariophysi, Siluriformes) e redefinição de seus gêneros. Unpublished $\mathrm{Ph}$. D. Thesis. Universidade de São Paulo. São Paulo. 599p.

Bockmann, F. A. \& G. M. Guazzelli. 2003. Family Heptapteridae (Heptapterids). Pp. 406-431. ln: Reis, R. E., S. O. Kullander \& C. J. Ferraris Jr. (Orgs.). Check list of the freshwater fishes of South and Central America. Porto Alegre, Edipucrs, 729p.

Britto, M. R. 2003. Análise filogenética da ordem Siluriformes com ênfase na superfamília Loridarioidea (Teleostei, Ostariophysi). Unpublished Ph. D. Thesis. Universidade de São Paulo. São Paulo. 512p.

Burns, J. R., A. D. Meisner, S. H. Weitzman \& L. R. Malabarba. 2002. Sperm and spermatozeugma ultrastructure in the inseminating catfish, Trachelyopterus lucenai (Ostariophysi: Siluriformes, Auchenipteridae). Copeia, 2002: 173-179.

Diogo, R. 2003. Higher-level phylogeny of Siluriformes - An overview. Pp. 353-384. In: Arratia, G., B. G. Kapoor, M. Chardon \& R. Diogo (Eds.). Catfishes. Enfield, Science Publishers, 828p.

Emel'yanova, N. G. \& A. P. Makeyeva. 1991a. Morphology of the gametes of the channel catfish Ictalurus punctatus. Voprosy Iktiologii, 31: 143-148.

Emel'yanova, N. G. \& A. P. Makeyeva. 1991b. Ultrastructure of spermatozoids of some representative catfishes. Voprosy Iktiologii, 31: 1014-1019. 
Emel'yanova, N. G. \& A. P. Makeyeva. 1992. Ultrastructure of spermatozoids of some representative catfishes. Journal of Ichthyology, 32: 127-134.

Ferraris, C. J. 2003. Genus and species Incertae Sedis in Siluriformes. Pp. 254. ln: Reis, R. E., S. O. Kullander \& C. J. Ferraris Jr. (Orgs.). Check list of the freshwater fishes of South and Central America. Porto Alegre, Edipucrs, 729p.

Jamieson, B. G. M. 1991. Fish evolution and systematics: evidence from spermatozoa. Cambridge, Cambridge University Press, 319p.

Jaspers, E. J., J. W. Avault \& J. D. Roussel. 1976. Spermatozoal morphology and ultrastructure of channel catfish, Ictalurus punctatus. Transactions of the American Fishery Society, 105: 475-480.

Kim, K. H. \& Y. H. Lee. 2000. The ultrastructure of spermatozoa of the ussurian bulhead, Leiocassis ussuriensis (Teleostei, Siluriformes, Bagridae) with phylogenetic considerations. Korean Journal of Limnology, 33: 405-412

Kwon, A. S., K. H. Kim \& Y. H. Lee. 1998. Ultrastructure of spermatozoa in the catfish Silurus asotus. Development and Reproduction, 2: 75-80.

Lee Y. H. 1998. The ultrastructure of spermatozoa in the bagrid catfish, Pseudobagrus fulvidraco (Teleostei, Siluriformes, Bagridae). Korean Journal of Electron Microscopy, 28: 3948.

Lee Y. H. \& K. H. Kim. 2001. The ultrastructure of spermatozoa in the slender catfish Silurus microdorsalis (Teleostei, Siluriformes, Siluridae) with phylogenetic considerations. Journal of Submicroscopy Cytology and Pathology, 33: 329-336.

Lopes, D. C. J. R., N. Bazzoli, M. F. G. Brito \& T. A. Maria. 2004. Male reproductive system in the South American catfish Conorhynchus conirostris. Journal of Fish Biology, 64: 1419-1424.

Lundberg J. G., A. H. Bornbusch \& F. Mago-Lécia. 1991. Gladioglanis conquistador $n$. $s p$. from Ecuador, with diagnoses of the subfamilies Rhamdiinae Bleecker and Pseudopimelodinae n. subf. (Siluriformes: Pimelodidae). Copeia, 1991: 190-209.

Maggese, M. C., M. Cukier \& V. E. Cussac. 1984. Morphological changes, fertilizing ability and motility of Rhamdia sapo (Pisces, Pimelodidae). Sperm induced by media of different salinities. Revista Brasileira de Biologia, 44: 541546.

Mansour N., F. Lahnsteiner F. \& C. A. Patzner. 2002. The spermatozoon of the African catfish: fine structure, mobility, viability and behavior in seminal vesicle secretion. Journal of Fish Biology, 60: 545-560.
Mattei, X. 1970. Spermiogenése comparé des poisson. Pp. 5772. In: Baccetti, B. (ed.). Comparative spermatology. New York, Academic Press. 773p.

Mattei, X. 1991. Spermatozoon ultrastructure and its systematic implications in fishes. Canadian Journal of Zoology, 69: 3038-3055.

Nath, A. \&. B. Chand. 1998. Ultrastructure of spermatozoa correlated with phylogenetic relationship between Heteropneustes fossilis and Rana tigrina. Cytobios, 95: 161-165.

Poirier, G. R. \& N. Nicholson. 1982. Fine structure of the testicular spermatozoa from the channel catfish, Ictalurus punctatus. Journal of Ultrastructural Research, 80: 104110.

Quagio-Grassiotto, I. \& E. D. Carvalho. 2000. Ultrastructure of Sorubim lima (Teleostei, Siluriformes, Pimelodidae) spermiogenesis. Journal of Submicroscopy Cytology and Pathology, 32: 654-659.

Quagio-Grassiotto, I., C. Oliveira. \& A. E. Gosztonyi. 2001. The ultrastructure of spermiogenesis and spermatozoa in Diplomystes mesembrinus. Journal of Fish Biology, 58: 1623-1632.

Quagio-Grassiotto, I. \& C. Oliveira (in press). Description of spermiogenesis and spermatozoa ultrastructure in Pimelodus maculatus and Pseudoplatystoma fasciatum (Siluriformes: Pimelodidae) showing the occurrence of a new type of spermiogenesis. Copeia.

Santos, J. E., N. Bazzoli, E. Rizzo \& G. B. Santos. 2001. Morphofunctional organization of the male reproductive system of the catfish Iheringichthys labrosus (Lutken, 1874) (Siluriformes: Pimelodidae). Tissue and Cell, 33: 533540.

Shibatta, O. A. 2003 Family Pseudopimelodidae (Bumblebee catfishes, dwarf marbled catfishes). Pp. 401-405. In: Reis, R.E., S.O. Kullander \& C.J. Ferraris Jr. (Orgs.). Check list of the freshwater fishes of South and Central America. Porto Alegre, Edipucrs, 729p.

Teugels, G. G. 1996. Taxonomy, phylogeny and biogeography of catfishes (Ostariophysi, Siluroidei); an overview. Aquatic Living Resources, 9: 9-34.
Received June 2005 Accepted August 2005 